\title{
Studying the Efficacy of Fipronil (WG 80\%) against Alfalfa Weevil, Hypera postica (Coleoptera: Curculionidae)
}

\author{
K. MOHAMMADPOUR ${ }^{1 *}$, M. JAFARLU ${ }^{2}$ and H. SOLTANI ${ }^{3}$ \\ ${ }^{1}$ Entomology Research Department, Iranian Research Institute of Plant Protection, Agricultural Research, \\ Education and Extension Organization (AREEO), Tehran, Iran \\ ${ }^{2}$ Agricultural and Natural Resources Research Centre of East Azerbaijan Province, Agricultural Research, \\ Education and Extension Organization (AREEO), Tabriz, Iran \\ ${ }^{3}$ Agricultural and Natural Resources Research Centre of Hamadan Province, Agricultural Research, \\ Education and Extension Organization (AREEO), Hamadan, Iran
}

(Received: 19 June 2018; accepted: 12 July 2018)

\begin{abstract}
The alfalfa weevil, Hypera postica Gyll. (Coleoptera: Curculionidae), is a key pest of alfalfa in different regions of the world where it causes sometimes complete crop destruction. Application of insecticides is the most important and major control method of this pest. The efficacy of fipronil (WG 80\%), 50, 70 and $90 \mathrm{~g} / \mathrm{ha}$ along with fosalon (EC 35\%), 2.5 1/ha and malathion (EC 57\%), 3 1/ha were assessed against this pest in the field based on a completely randomized block design. Based on Henderson-Tilton formula, on the fourteenth day after treatment, the minimum efficacy of fipronil, 50,70 and $90 \mathrm{~g} / \mathrm{ha}$, fosalon, $2.5 \mathrm{l} / \mathrm{ha}$ and malathion, $3 \mathrm{l} / \mathrm{ha}$ bait was $80 \%, 89 \%, 98 \%, 76 \%$ and $75 \%$, respectively. Results showed that fipronil (WG $80 \%$ ) at $50-70 \mathrm{~g} / \mathrm{ha}$ can be used against alfalfa weevil.
\end{abstract}

Keywords: Alfalfa weevil, Hypera postica, fipronil, efficacy.

The alfalfa weevil, Hypera postica (Gyll. 1813), is a key pest of alfalfa in different regions of the world. This introduced pest is the most noxious in the early season, causing defoliation and reduced yield and quality. Both adults and larvae feed on alfalfa, but the larvae cause the majority of the damage to terminals, foliage, and new crown shoots (Radcliffe and Flanders, 1998). Damage inflicted by alfalfa weevil can cause significant loss of biomass, especially leaf tissue, and also slow growth and delay crop maturity (Onstad and Shoemaker, 1984; Hutchins et al., 1990). Larvae hatch into sheltered alfalfa stems near the ground, and will typically feed and grow for 2-4 weeks before pupating, depending on temperature (Radcliffe and Flanders, 1998). Alfalfa weevil has four instars. Once larvae are mature, they pupate and form small, silk cocoons spun near the base of the alfalfa plant. Adults have been shown to estivate, or enter into dormancy, in the summer months, leaving alfalfa fields to hide under plant litter or tree bark in field edges (Reynolds et al., 1955; Prokopy et al., 1967; Blickenstaff et al., 1972).

\footnotetext{
* Corresponding author; e-mail: mohammadpour_k@yahoo.com
} 
The insecticides that target the larval stage include organophosphates, carbamates and pyrethroids. Some products use a combination of two of these insecticide classes. Decisions about using insecticides should be made by scouting and calculating the economic threshold. Another important consideration in using insecticides to treat for alfalfa weevil is toxicity to bees and natural enemies. Many products registered for use for alfalfa weevil have high or moderate toxicities to natural enemies, and can be highly toxic to bees (Wright et al., 2015).

The goal of this research was to study the efficacy of fipronil (Solitaire WG 80\%) against $H$. postica in the field. Fipronil is a broad range insecticide that belongs to the phenylpyrazole chemical family. It disrupts the insect central nervous system by blocking GABA-gated chloride channels and glutamate-gated chloride ( $\mathrm{GluCl}$ ) channels, resulting in central nervous system toxicity. This causes by hyperexcitation of contaminated insects' nerves and muscles. It is effective on contact or ingestion. Fipronil is used to control ants, beetles, cockroaches, fleas, ticks, termites, mole crickets, thrips, rootworms, weevils, and other insects. Fipronil sticks tightly to soil and does not mix very well with water. Therefore, it does not move much in the soil and is not expected to leach into groundwater.

\section{Materials and Methods}

The research was conducted based on a completely randomized block design with five treatments and four replications during 2018 in Tabriz (East Azerbaijan, Iran) and Pakdasht (Tehran, Iran). Treatments were 1) fipronil (WG 80\%), $70 \mathrm{~g} / \mathrm{ha}, 2$ ) fipronil (WG $80 \%$ ), $90 \mathrm{~g} / \mathrm{ha}, 3$ ) fosalon (EC 35\%), 2.5 1/ha, 4) malathion (EC 57\%), 3 1/ha and 5) control (no-spray treatment). Also, based on the preliminary results, fipronil (WG 80\%), $50 \mathrm{~g} / \mathrm{ha}$ and fipronil (WG 80\%), $70 \mathrm{~g} / \mathrm{ha}$ was tested with other treatments in Hamadan (Iran). The treatments were applied in a one ha alfalfa field in March 2018. Each plot was $50 \mathrm{~m}^{2}$ with $1 \mathrm{~m}$ border for each plot. The number of larvae was recorded one day before treatment and 2, 7 and 14 days after treatment. The efficacy of treatments was estimated based on the Henderson-Tilton formula (Henderson and Tilton, 1955):

$$
\text { Efficacy } \%=100 \times[1-(T a \times C b) /(T b \times C a)]
$$

where, $T a$ is the number of larvae in treated plot after treatment, $C b$ is the number of larvae in control plot before treatment, $T b$ is the number of larvae in treated plot before treatment, and $\mathrm{Ca}$ is the number of larvae in control plot after treatment.

Data were analysed using procedures of SAS (SAS Institute Inc., 2002). The normality of the untransformed and transformed data and normality of residuals after analysis of variance were checked using stem-leaf and normal probability plots. Homoscedasticity was checked by observing graphical distribution plots of variance by mean (PROC PLOT). A General Linear Model (PROC GLM) was used to compare the efficacy of the treatments $(\alpha=0.05)$. Comparisons between the treatments were made using the Tukey test, where analysis of variance showed significant differences among means. 


\section{Results and Discussion}

\section{Tabriz (East Azerbaijan, Iran)}

The analysis of variance of data showed that there was a significant difference among treatments on the second $(\mathrm{F} 3,9=25.68, \mathrm{P}<0.0001)$, seventh $(\mathrm{F} 3,9=24.53$, $\mathrm{P}<0.0001)$ and fourteenth $(\mathrm{F} 3,9=4.08, \mathrm{P}=0.0005)$ day after the application. In all dates, the highest efficacy was observed in fipronil, $90 \mathrm{~g} / \mathrm{ha}$ followed by fipronil, $70 \mathrm{~g} / \mathrm{ha}$. The mortality rates between fipronil, $90 \mathrm{~g} / \mathrm{ha}$ and fipronil, $70 \mathrm{~g} / \mathrm{ha}$ was not significantly different based on Tukey test (Table 1). In all treatments, the efficacy was higher on the seventh and fourteen day after application compared to the second day after application. The fosalon (EC 35\%), 2.5 1/ha and malathion (EC 57\%), 3 1/ha insecticides show acceptable control against alfalfa weevil.

\section{Pakdasht (Tehran, Iran)}

The analysis of variance of data showed that there was a significant difference among treatments on the second $(\mathrm{F} 3,9=11.70, \mathrm{P}=0.0019)$ and seventh $(\mathrm{F} 3,9=4.95$, $\mathrm{P}=0.0267$ ) day after the application. In both dates, the highest efficacy was observed in fipronil, $90 \mathrm{~g} / \mathrm{ha}$ followed by fipronil, $70 \mathrm{~g} / \mathrm{ha}$. The mortality rates among fipronil, $90 \mathrm{~g} /$ ha, fipronil, $70 \mathrm{~g} / \mathrm{ha}$ and malathion (EC 57\%), 3 1/ha were not significantly different based on Tukey test (Table 2). In all treatments, the efficacy was higher on the seventh and

\section{Table 1}

Mean ( \pm SE) efficacy of different insecticides applied against alfalfa weevil, Hypera postica Gyll. (Coleoptera: Curculionidae) in alfalfa field at Tabriz (East Azerbaijan, Iran) in 2018

\begin{tabular}{llll}
\hline Treatments & \multicolumn{3}{c}{ Mean $( \pm$ SE) efficacy } \\
\cline { 2 - 4 } & $\begin{array}{l}\text { Second day } \\
\text { after application }\end{array}$ & $\begin{array}{l}\text { Seventh day } \\
\text { after application }\end{array}$ & $\begin{array}{l}\text { Fourteenth day } \\
\text { after application }\end{array}$ \\
\hline Fipronil (WG 80\%), 90 g/ha & $96.62 \pm 1.60 \mathrm{a}$ & $99.27 \pm 0.73 \mathrm{a}$ & $98.81 \pm 1.18 \mathrm{a}$ \\
Fipronil (WG 80\%), 70 g/ha & $89.23 \pm 4.22 \mathrm{ab}$ & $96.91 \pm 0.78 \mathrm{a}$ & $93.24 \pm 3.48 \mathrm{ab}$ \\
Fosalon (EC 35\%), 2.5 1/ha & $77.96 \pm 4.97 \mathrm{bc}$ & $79.86 \pm 2.98 \mathrm{~b}$ & $80.26 \pm 1.71 \mathrm{bc}$ \\
Malathion (EC 57\%), 3 1/ha & $68.15 \pm 3.35 \mathrm{c}$ & $78.20 \pm 3.22 \mathrm{~b}$ & $76.71 \pm 2.90 \mathrm{c}$ \\
\hline
\end{tabular}

Means in a column followed by same letter were not significantly different $(a=0.05)$

Table 2

Mean ( \pm SE) efficacy of different insecticides applied against alfalfa weevil, Hypera postica Gyll. (Coleoptera: Curculionidae) in alfalfa field at Pakdasht (Tehran, Iran) in 2018

\begin{tabular}{lccc}
\hline Treatments & \multicolumn{3}{c}{ Mean $( \pm$ SE) efficacy } \\
\cline { 2 - 4 } & $\begin{array}{l}\text { Second day } \\
\text { after application }\end{array}$ & $\begin{array}{l}\text { Seventh day } \\
\text { after application }\end{array}$ & $\begin{array}{l}\text { Fourteenth day } \\
\text { after application }\end{array}$ \\
\hline Fipronil (WG 80\%), 90 g/ha & $91.28 \pm 0.65 \mathrm{a}$ & $99.33 \pm 0.46 \mathrm{a}$ & $100.00 \pm 0.00 \mathrm{a}$ \\
Fipronil (WG 80\%), 70 g/ha & $91.06 \pm 2.42 \mathrm{a}$ & $98.92 \pm 0.23 \mathrm{a}$ & $99.95 \pm 0.04 \mathrm{a}$ \\
Fosalon (EC 35\%), 2.5 1/ha & $80.68 \pm 4.31 \mathrm{ab}$ & $94.42 \pm 3.08 \mathrm{ab}$ & $85.20 \pm 9.90 \mathrm{a}$ \\
Malathion (EC 57\%), 3 1/ha & $60.12 \pm 9.52 \mathrm{~b}$ & $79.83 \pm 8.36 \mathrm{~b}$ & $92.36 \pm 2.57 \mathrm{a}$ \\
\hline
\end{tabular}

Means in a column followed by same letter were not significantly different $(a=0.05)$ 
fourteenth day after application compared to the second day after application. The fosalon (EC 35\%), 2.5 1/ha and malathion (EC 57\%), 3 1/ha insecticides show acceptable control against alfalfa weevil (Table 2).

\section{Hamadan (Iran)}

The analysis of variance of data showed that there was a significant difference among treatments on the seventh $(\mathrm{F} 3,9=14.32, \mathrm{P}=0.0009)$ and fourteenth $(\mathrm{F} 3,9=15.74$, $\mathrm{P}=0.0006)$ day after the application. In both dates, the highest efficacy was observed in fipronil, $70 \mathrm{~g} / \mathrm{ha}$ followed by fipronil, $50 \mathrm{~g} / \mathrm{ha}$. The mortality rates among fipronil, $70 \mathrm{~g} / \mathrm{ha}$, fipronil, $50 \mathrm{~g} / \mathrm{ha}$ was not significantly different based on Tukey test (Table 3). In all treatments, the efficacy was less on the seventh and higher in fourteenth day after application compared to the second day after application. The fosalon (EC 35\%), 2.5 1/ha and malathion (EC 57\%), 3 1/ha insecticides show acceptable control against alfalfa weevil (Table 3).

\section{Table 3}

Mean $( \pm$ SE) efficacy of different insecticides applied against alfalfa weevil, Hypera postica Gyll. (Coleoptera: Curculionidae) in alfalfa field at Hamadan (Iran) in 2018

\begin{tabular}{llll}
\hline Treatments & \multicolumn{3}{c}{ Mean $( \pm$ SE) efficacy } \\
\cline { 2 - 4 } & $\begin{array}{l}\text { Second day } \\
\text { after application }\end{array}$ & $\begin{array}{l}\text { Seventh day } \\
\text { after application }\end{array}$ & $\begin{array}{l}\text { Fourteenth day } \\
\text { after application }\end{array}$ \\
\hline Fipronil (WG 80\%), 70 g/ha & $87.96 \pm 0.70 \mathrm{a}$ & $87.12 \pm 0.85 \mathrm{a}$ & $89.16 \pm 0.61 \mathrm{a}$ \\
Fipronil (WG 80\%), 50 g/ha & $83.89 \pm 3.32 \mathrm{a}$ & $80.63 \pm 2.36 \mathrm{ab}$ & $83.31 \pm 1.45 \mathrm{ab}$ \\
Fosalon (EC 35\%), 2.5 1/ha & $75.17 \pm 4.40 \mathrm{a}$ & $67.12 \pm 3.35 \mathrm{~b}$ & $75.56 \pm 2.08 \mathrm{~b}$ \\
Malathion (EC 57\%), 3 1/ha & $81.71 \pm 0.87 \mathrm{a}$ & $73.93 \pm 2.39 \mathrm{~b}$ & $77.41 \pm 3.43 \mathrm{~b}$ \\
\hline
\end{tabular}

Means in a column followed by same letter were not significantly different $(a=0.05)$

Application of fipronil (WG 80\%) at 40 and $50 \mathrm{~g}^{\mathrm{g}}$ a.i. ha ${ }^{-1}$ against leaf folder on rice, Cnaphalocrocis medinalis, were caused $76.5 \%$ and $77.5 \%$ percent reduction of leaf damage and showed better efficacy than chlorpyrifos (EC 20\%) at $200 \mathrm{~g}$ a.i. ha ${ }^{-1}$. Fipronil (WG 80\%) at 40 and $50 \mathrm{~g}$ a.i. ha ${ }^{-1}$ did not have phytotoxicity to rice and were safe to Trichogramma chilonis Ishii with 80 percent emergence and parasitisation (Shanmuga et al., 2017). Application of fipronil (WG 80\%) at 100, 80, 50 and $40 \mathrm{~g}$ a.i. ha ${ }^{-1}$ against thrips on grape showed the reduction in thrips damage by $82.2,81.7,82.0$ and $81.8 \%$, respectively. There were no symptoms of phytotoxicity in the treated plots. Also, application of fipronil (WG 80\%) at $40 \mathrm{~g}$ a.i. ha ${ }^{-1}$ and $50 \mathrm{~g}$ a.i. ha ${ }^{-1}$ in the laboratory caused $32.5 \%$ and $40 \%$ mortality of Coccinellid, Cryptolaemus montrouzieri adults, however it was safer compared to conventional insecticides, chlorpyrifos (EC 20\%) at $200 \mathrm{~g}$ a.i. $\mathrm{ha}^{-1}$ and dimethoate (EC 30\%) at $375 \mathrm{~g}^{\text {a.i. }} \mathrm{ha}^{-1} 24$ hours after treatment (Shanmuga et al., 2016). Application of fipronil (WG 80\%) at 62.5-75 g.a.i. ha ${ }^{-1}$ was effective against diamond back moth, Plutella xylostella. Also, no adverse effect was observed on different Coccinelids and parasite Cotesia plutellae (Wale and Chandele, 2010). 


\section{Compliance with ethical standards:}

Funding: This study was not funded by any organization.

Conflict of Interest: None of the authors has any conflict of interest to declare.

Ethical approval: This article does not contain any studies with human participants or animals performed by any of the authors.

\section{Literature}

Blickenstaff, C. C., Huggans, J. L. and Schroder, R. W. (1972): Biology and ecology of the alfalfa weevil, Hypera postica, in Maryland and New Jersey 1961 to 1967. Annals of the Entomological Soc. of America 65, 336-349.

Henderson, C. F. and Tilton, E. W. (1955): Tests with acaricides against the brown wheat mite. J. Econ. Entomol. 48, 157-161.

Hutchins, S. H., Buntin, G. D. and Pedigo, L. P. (1990): Impact of insect feeding on alfalfa regrowth: A review of physiological responses and economic consequences. Agronomy J. 82, 1035-1044.

Onstad, D. W. and Shoemaker, C. A. (1984): Management of alfalfa and the alfalfa weevil (Hypera postica): An example of systems analysis in forage production. Agricultural Systems 14, 1-30.

Prokopy, R. J., Armbrust, E. J., Cothran, W. R. and Gyrisco, G. G. (1967): Migration of the alfalfa weevil, Hypera postica (Coleoptera: Curculionidae), to and from estivation sites. Annals of the Entomol. Soc. of America 60, 26-31.

Radcliffe, E. B. and Flanders, K. L. (1998): Biological control of alfalfa weevil in North America. Integrated Pest Management Reviews 3, 225-242.

Reynolds, H. T., Anderson, L. D. and Deal, A. S. (1955): The Egyptian alfalfa weevil and its control in Southern California. J. Econ. Entomol. 48, 297-300.

SAS Institute Inc. (2002): SAS/STAT user's guide. Version 9.1. SAS Institute Inc., Cary, North Carolina.

Shanmuga, P. M., Sridharan, S. and Kuttalam, S. (2016): Fipronil 80WG-A promising phenyl pyrazole insecticide to manage thrips damage in grapes. Annals of Plant Protection Sci. 24, 61-66.

Shanmuga, P. M., Sridharan, M. and Kuttalam, S. (2017): Management of rice leaf folder with fipronil 80 WG A novel phenyl pyrazole pesticide. Pestology 41, 26-31.

Wale, S. D. and Chandlele, A. G. (2010): Evaluated a new product in the India market, fipronil 80 WG, against diamond back moth on cabbage. Pestology 34, 17-19.

Wright, R. J., Bradshaw, J. D., Jarvi, K .J. and Rethwisch, M. (2015): 2016 Guide for Weed, Disease, and Insect Management in Nebraska. EC 130. University of Nebraska Lincoln, Lincoln, NE. 